\title{
Evolving Ethio-Gulf Economic and Political Relations: The Challenges and Opportunities
}

\author{
Bekele Jemallu Jenber \\ School of International and Public Affairs, Jilin University, Changchun, China \\ Email: jemalu06@yahoo.com
}

How to cite this paper: Jenber, B. J. (2021). Evolving Ethio-Gulf Economic and Political Relations: The Challenges and Opportunities. Open Journal of Social Sciences, 9, 267-287.

https://doi.org/10.4236/jss.2021.910019

Received: September 7, 2021

Accepted: October 24, 2021

Published: October 27, 2021

Copyright $\odot 2021$ by author(s) and Scientific Research Publishing Inc. This work is licensed under the Creative Commons Attribution International License (CC BY 4.0).

http://creativecommons.org/licenses/by/4.0/

\begin{abstract}
Despite historical and religious ties, geographical proximity, and other opportunities for mutual benefit, the overall relations between Ethiopia and the Gulf Cooperation Council (GCC) countries have remained ambivalent for many years. This study examines Ethiopia's economic and political relations with the Gulf countries since 2000 and the challenges that hindered and opportunities that can further improve their relationship. The study argues that while their economic relations have been developing steadily over the past two decades, especially since the political transition in Ethiopia in 2018, their political relations remained weak. Their relationship is not based on evenly balanced mutual dependence; rather it is asymmetric as the Gulf countries are relatively less dependent in the interdependence relationship. The study also finds out that the perception of the Gulf countries' elites considering Ethiopia as a Christian empire and Ethiopian elites' skepticism of the Arab world due to past hostile political relations; the GCC countries' support of Egypt in the Nile disputes; and mistreatment of Ethiopian migrants in some GCC countries are among the key challenges undermining their relations.
\end{abstract}

\section{Keywords}

Ethiopia, Ethio-Gulf, GCC, Political Relations, Economic Relations

\section{Introduction}

Ethiopia is a country with long historical, religious, and economic ties with the Gulf Cooperation Council (GCC) member countries and peoples. The GCC is a regional organization, which consists of six oil-producing Gulf countries, Saudi Arabia, Bahrain, Kuwait, Oman, Qatar, and the United Arab Emirates (UAE). It was established in 1981 to enhance cooperation among the member countries and their peoples and establish similar systems in economic, finan- 
cial, education, technology, legislation, administration, and other fields. Ethiopia's relationship with the Gulf starts before the seventh century A.D. from long-distance trade relations, but primarily the rise of Islam laid the foundation for the relationship. Ethiopia established formal diplomatic relations with all the GCC member states. However, this long-standing bond has not developed as much as it should have into strong economic and political ties and mutual benefits.

During the pre-1974 imperial regime, there was a great deal of suspicion and distrust between Ethiopia and the GCC countries. Due to Ethiopia's strong historical and traditional ties with Israel and the Orthodox Christianity-dominated political and economic system at home, Arab countries viewed Ethiopia as an adversary of the Arab world. As a result, the Arab GCC countries sided with both internal and external opponents of the Ethiopian government. During the Derg regime (from 1974-1991), similar mistrust and suspicion continued to grow with each other.

Although the economic and political relations between the two sides have shown improvements during the EPRDF regime (1991-2018), it was not free from mutual suspicion and mistrust. Neither Ethiopia nor the Arab world has benefited from this long-standing mutual mistrust and suspicion. They couldn't utilize the massive potentials for strong economic and political ties. However, following the political transition in Ethiopia in 2018, the situation has begun to change significantly and Ethiopia's relations with the GCC countries have further improved. As discussed below in detail, the Ethiopian government has shown its interest to work closely and cooperate with the Gulf countries in the last three years. Ethiopia and the Gulf countries signed several agreements to improve their overall relationship.

The study of Ethio-GCC relations is important for many reasons. From the Ethiopian perspective, relations with the GCC countries are very significant because 1) The GCC countries are the reliable suppliers of fuel to Ethiopia. Saudi Arabia was one of the main suppliers of fuel to Ethiopia for the last many years, while recently Kuwait and the UAE have become the suppliers of the bulk of its oil consumption. 2) The GCC countries have the largest economy, which enabled them to have a significant influence not only in the Arab world but also in the Horn of Africa. Their economic power makes them very important economic and political partners to maintain close and friendly relations for Ethiopia. 3) The GCC countries, especially Saudi Arabia, Qatar, and the UAE are strengthening their economic, political, and military influences in the Horn of Africa. They built their military bases in Djibouti, Sudan, Eritrea, and Somalia. Some of them are investing in the development of ports in the region. Politically, they are also playing their role in Somalia's and Sudan's political conditions. Since Ethiopia is a landlocked country located in the Horn of Africa, these GCC countries' influences in the region have direct implications in its domestic political and economic conditions and regional security.

For the GCC countries, their relations with Ethiopia are also important be- 
cause: 1) Ethiopia is one of the fast-growing economies and the second most populous countries in Africa, which makes the country a potential consumer market for the GCC countries' oil and other export commodities. 2) Ethiopia is an influential country in the Horn of Africa. It is the seat of the African Union and the United Nations Economic Commission for Africa (UNECA). The GGC countries' strong relations with Ethiopia would help them to achieve their interests in the sub-region and the broader Africa. 3) The GCC countries are entirely dependent on imported food. To ensure their food security, they want to expand investment in Agriculture abroad. As Ethiopia is conducive to agricultural investment, they want to establish close relations with Addis Ababa. Moreover, both the Gulf and the Horn of Africa (where Ethiopia is located) have a common regional security threat, which makes their strong relationship important.

Due to these reasons, the study focuses on Ethiopia's relations with the GCC countries. Although the relationship between Ethiopia and the GCC countries has a long history and multifaceted nature, it has not been adequately studied. Therefore, the study is significant to understand the nature, extent, challenges, and opportunities of the relations between the two sides. The study tries to answer, what is the existing level of cooperation? What are the mutually beneficial opportunities? And what are the challenges they are facing in their relations? Based on these questions, it examines Ethiopia's historical relationship with the GCC countries. The study also identifies the potential opportunities for further enhancement of economic and political ties and mutual trust as well as the challenges hindering their relationships. The study employs a qualitative research method and explanatory approach. It uses secondary sources of data like books, academic journals, official reports, media reports, and others. The study also employed the theory of complex interdependence that emphasizes the complex ways in which due to the growing ties, states become mutually dependent, sensitive to each other's needs, and vulnerable to each other's actions in world politics.

\section{Theoretical Framework}

The theory of complex interdependence is widely associated with two famous scholars, Robert Keohane and Joseph Nye. They developed the theory in the 1970 s to describe the growing interdependence in the international political economy. The theory argues that all actors including states and non-state actors in the contemporary globalized world are mutually interdependent. As explained by Keohane and Nye, "interdependence means mutual dependence. Interdependence in world politics refers to situations characterized by reciprocal effects among countries or among actors in different countries" (Robert \& Nye, 1977).

The theory emphasizes that due to the growing ties among actors in the global political economy, states become interdependent, sensitive to each other's needs, and vulnerable to each other's actions. Under this mutual dependence, the relationship between states is significantly characterized by both cooperation and completion. In this interconnected world, the policies and actions of one state 
can affect the policies and actions of other states. The behavior of one state can have a significant impact on others' behavior. Interdependence does not necessarily mean only cooperation and peace among actors. The relationship between actors can also be characterized by cooperation, dependence, and interaction in conflict (Rana, 2015).

In a mutually dependent relationship, the theory argues, both benefits and costs need to be taken into consideration. Despite the growing economic cooperation and mutual benefits in the interdependent international political economy, the possibility of competition and conflict is unavoidable. In this regard, Keohane and Nye stated that "the politics of economic and ecological interdependence involve competition even when large net benefits can be expected from cooperation" (Robert \& Nye, 1977).

They also further argued that interdependence should not be considered as "evenly balanced mutual dependence." Rather "it is asymmetries in dependence that are most likely to provide sources of influence for actors in their dealings with one another. Less dependent actors can often use the interdependence relationship as a source of power in bargaining over an issue and perhaps to affect other issues" (Ibid).

The basic features and assumptions of the complex interdependence theory best fit to understand the relationship between Ethiopia and the Gulf Cooperation Council Countries. As noted above, their relationship is characterized by mutual benefit and mutual dependence. The more they strengthen their cooperation the more they mutually benefit and vice versa. At the same time, their relationship is characterized by mutual suspicions, rivalries, and competition in some issues. Therefore, the study uses the theory of complex interdependence to explain and analyze the Ethio-Gulf relations.

\section{Ethiopia's Relations with the GCC Countries under Successive Regimes}

Ethiopia and the GCC countries share an intensive and long history. Religion has an important place in their historical relationships. Although their trade ties have been around for a long time, the relationships between Ethiopia and the GCC countries were strengthened following the rise of Islam.

Historical relations between the two regions date back to 615 A.D. when followers of Prophet Mohammad flee to Aksum upon his advice. King Al-Najashi Ashama has received the migrants and they were settled in Negash, a village in the present-day Tigray region (Erlich, 2006). This marked the beginning of religious ties between Ethiopia and the Arab world. However, these remarkable historical and religious ties between Ethiopia and the Arab world were not used to further mutual benefits for a long time.

The Christian-centric domestic policies of the successive imperial regimes of modern Ethiopia were among the reasons behind the weak relationship between Ethiopia and the GCC countries. The successive rulers of Ethiopia have per- 
ceived Ethiopia as a "Christian island surrounded by Muslim cultures" (Sorenson, 1992). This perception seriously influenced Ethiopia's relations with the Gulf and the Middle East as a whole until recently.

Another most important factor that strained this relation and aggravated the anti-Ethiopia sentiment in the GCC countries was Mussolini's propaganda of the 1930s. To realize his dream of colonizing Ethiopia, Mussolini designed a strategy to create division among the Ethiopian Muslims and Christians and to mobilize support from the Muslim world. He aimed to implement the divide and rule policy. To this end, he depicted Ethiopia as a brutal Christian kingdom that had oppressed its Muslim population and Islam (Erlich, 1994). Mussolini had tried to permeate anti-Ethiopia sentiment in the minds and hearts of his followers in the Middle East. He had also encouraged and sponsored anti-Ethiopia writings in the Arab world, which significantly changed the image of Ethiopia in the minds of the Muslim Arabs.

Moreover, the Arab-Israeli conflict and Ethiopia's strong tie with Israel was also another reason that made Ethiopia's relations with the Muslim and Arab countries complex and full of tension during Emperor Haile Selassie. In direct response to that, some Arab countries supported the Eritrean rebels and Somalia's claim of Somali inhabited Ethiopian territory. They financed the Eritrean People's Liberation Front (EPLF) in its struggle for secession (Birara, 2013).

Ethiopia's confrontation with the Arab world has also been worsened during the rule of the military regime (1974-1991). In the late 1970s, some Arab countries' support of Somalia in the Ethio-Somalia war and their continued support to Eritrean rebels critically hampered Ethiopia's relations with the Arab countries. As mentioned by the International Crisis Group (2019), Saudi Arabia, as a strong partner of the US, has invested a lot of resources to remove the Soviet-backed military regime in Ethiopia. As a result, the Ethiopian military /Socialist regime had perceived most of the Arab countries in the Middle East as historical enemies of the country (Adula, 2019; Tekle, 1989). Nevertheless, in the late 1980s, as its support from the Soviet Union declined, the Ethiopian government had attempted to improve its relations with the Arab countries. High-level Ethiopian delegations, including the president, had visited some leading Arab countries, including Saudi Arabia, and attempted to convince them to stop their support to the Eritrean rebel group (Ofcansky \& Berry, 1991). Despite this effort, the relations between Ethiopia and the Arab world remained dormant and hostile.

The Ethio-Arab relations have begun to improve following the downfall of the military regime in 1991. The new Ethiopian People's Revolutionary Democratic Front (EPRDF) led government has tried to strengthen its ties with the GCC countries. The important factor that contributed to this development was the separation of Eritrea from Ethiopia. EPRDF's measures to ensure religious equality and Ethiopia's foreign policy shift from outward-looking to inward-looking approach also supported the relationship. As one of the emphases 
of the new foreign policy direction was trade and economic development, the government needed foreign direct investment and markets for agricultural products. To this end, it established relatively better relations with the GCC countries, especially with Saudi Arabia, the UAE, Qatar, and Kuwait.

Most importantly, Ethiopia's relations with the Gulf have shown fundamental progress following the 2018 political transition in Ethiopia. The political change in Ethiopia, which led to the coming of Abiy Ahmed to power, coupled with the growing interest of the GCC countries in the Horn of Africa, allows Ethiopia and the Gulf to get closer to each other and to have a relatively better and stronger relationship.

\section{Ethio-Gulf Economic and Political Relations since 2000}

As indicated above, Ethiopia's economic and political relations with the GCC countries have begun to improve following the coming of the EPRDF regime to power. This relationship has shown significant development since the 2000s. In the 1990s, Ethiopia was struggling to recover from the damage of the civil war and to create a stable internal political and economic system. In the meantime, it went to another bloody war with neighboring Eritrea from 1998 to 2000, which weakened the reviving economy of the country and further complicated regional peace and security. To recover from the economic and political wounds of the war, Ethiopia gave more emphasis to improve its foreign relations. The formulation and launching of the Ethiopian Foreign and National Security Policy in 2002 was another important event that guided the country's foreign relations, including its relations with the Gulf countries. Internationally, the global oil prices were sharply increased in the early 2000s, which led to the high transfer of income from oil-consuming countries to oil-producing countries. This phenomenon has maximized the revenues of the oil-producing Gulf countries and enabled them to expand their economy and investment abroad, including Ethiopia. The late 2000s dramatic increase in world food prices also further enhanced the economic interests of the GCC countries in Ethiopia. To fulfill their food demand, they began to invest in the agriculture sector in Ethiopia, which improved the relationship between the two sides. These domestic and international political and economic changes in the 2000s had their own marks on the Ethio-Gulf relationships.

\subsection{Economic Relations}

Ethiopia's economic (trade and investment) relations with GCC countries have shown significant progress in the last two decades. The oil-rich GCC countries have strong economic power with vast potential for Foreign Direct Investment (FDI). These countries are working to minimize their oil dependence by diversifying their economy. Ethiopia, on the other hand, has offered investment opportunities in agriculture, manufacturing, and service sectors for GCC countries which are compatible with the latter's goals of diversifying their economy. This 
section discusses the trade and investment relationship between the two sides.

\subsubsection{Trade}

The trade relations between Ethiopia and the Gulf have been started long ago. However, the trade exchange was very limited until the early 2000s. Recently, the GCC countries, especially, Saudi Arabia, the UAE, and Kuwait have become among the top trading partners of Ethiopia.

Saudi Arabia is one of the main trading partners of Ethiopia. The trade relationship between the two is growing from time to time. According to the data from Encyclopedia of the Nations (2021), in 2000, Ethiopia's export value to Saudi Arabia was 39 million USD, while its import value was 21 million USD. The trade turnover was only 60 million USD. But, still, Saudi Arabia was the third top trading partner of Ethiopia. The data obtained from the African Union yearbook of 2020 show that in 2019, Ethiopia's export value has become 171.62 million USD, while the import value has grown to 460.78 . The total trade turnover in the same year was 632.4 million USD. From 2015 to 2019, Saudi Arabia was one of the top trading partners of Ethiopia with a total trade turnover of more than 2.85 billion USD. Ethiopia imported nearly 2.05 Billion USD worth of goods from Saudi Arabia and exported 807.22 million USD of goods to Saudi Arabia in these five years. The trade balance shows that the trade relation between Ethiopia and Saudi Arabia was in favor of Saudi Arabia. From the total export trade volume of Ethiopia, 8.13 percent was exported to Saudi Arabia, which makes Saudi Arabia one of the main export destinations of Ethiopian goods.

The UAE is another strong trade partner of Ethiopia. The trade relationship between Ethiopia and the UAE has also shown great improvement in the last ten years. According to the data from the African Union yearbook of 2020, the total trade turnover between Ethiopia and the UAE from 2015 to 2019 was more than 2.47 billion USD. In 2015, it was 460.99 million and it reached 580 million USD in 2019. The trade relationship between the two countries was in favor of the UAE as Ethiopia imported more than 1.9 billion USD goods from the UAE, while it exported 525.96 million USD goods to the UAE. The UAE was one of the top four of Ethiopia's export destinations in the years under consideration. Agricultural products and semi-processed commodities are the main export items of Ethiopia, while it imports Petroleum, vehicles, electronics, machinery, fertilizers, and other consumer goods from the UAE.

Kuwait was another most important trading partner of Ethiopia. According to the UN Comtrade Database, Kuwait was among the top three destinations of Ethiopia's merchandise exports from 2015 to 2018 with an average of 11.3 percent of total exports. It was also among the top three partners for merchandise imports with an average of 6.4 percent of total imports of the country. Ethiopia exports agricultural products and live animals to Kuwait, while it imports petroleum from the latter. 
Ethiopia's trade relation with Qatar has not reached the desired level. The total trade turnover between the two was 22.3 million USD in 2008 and declined to 5.8 million USD in 2018. The trade balance was in favor of Qatar. In the past ten years, Ethiopia exported 4.9 million USD of goods to Qatar and imported 172.4 million USD worth of goods. Ethiopia imported fertilizer, plastic products, petroleum oil, and others and exported agricultural products (Girma, 2020).

Ethiopia's trade ties with Bahrain and Oman are not well developed. For instance, according to the data from the Trading Economics (2021) database, Ethiopia exports agricultural commodities and live stocks of only 4.88 Million and 588.5 thousand USD to Oman in 2017 and 2018, respectively. Ethiopia imports 4.26 million USD in 2017 and 285.71 thousand USD in 2018 from Oman. Likewise, Ethiopia exports 5.59 Million USD agricultural commodities to Bahrain in 2018 and imports 66.32 Million USD industrial goods from Bahrain in 2017. However, efforts to improve trade relations between Ethiopia and these two countries are being pursued from both sides along the diplomatic lines.

\subsubsection{Investment}

To encourage and create favorable conditions for investors, and to mitigate their susceptibility to the challenges that can be encountered in a new and unfamiliar system, Ethiopia has signed bilateral investment treaties with Kuwait, the UAE, and Qatar in 1996, 2016, and 2017 respectively (UNCTAD, 2021). The treaties have recognized reciprocal protection of investments between the signing parties. The bilateral investment treaty between Ethiopia and Kuwait was entered into force, while the rest two are not in force.

As the GCC countries are dependent on imported food, they invest mainly in the agriculture sector in Ethiopia to ensure their food security. As indicated above, the rise in the oil prices since 2000 and food prices in the late 2000s encouraged and compelled the GCC countries like Saudi Arabia and the UAE to lease farmlands in Ethiopia. As reported by Meester, van den Berg, and Verhoeven (2018), the Gulf investments in Ethiopia in the 1990s were very limited, only 35. However, since 2000 the number of Gulf investments has increased and reached 365 in 2017. Saudi Arabia was the leading Gulf country to invest in Ethiopia, holding 233 agriculture and manufacturing investments from 2000-2017, followed by the UAE with 104 investments, Kuwait with 16 investments, and Qatar with 12 investments.

Although the investment flow to Ethiopia has shown a relative decline as a result of the political instability in different parts of the country since 2015, some GCC countries, like the UAE, Saudi Arabia, Kuwait, and Qatar have further strengthened their economic engagement in Ethiopia following the 2018 Ethiopian political transition. Especially, the UAE has been attracted by the political transition and the subsequent economic reforms in Ethiopia since 2018 and showed its willingness to invest in the country. UAE's growing desire to exploit the favorable economic conditions in Ethiopia coupled with its desire to keep its regional competitors away from the region encouraged Abu Dhabi to enhance 
its engagement in Ethiopia.

The UAE has committed 3 billion USD (one billion in assistance, which was immediately deposited in the National Bank of Ethiopia and two billion investments) (Cafiero \& Cok, 2020) to support the political and economic reforms of Ethiopia under the new government. An Abu Dhabi Real Estate Company, Eagle Hills, invested two billion USD (T.G., 2019) in a real estate project in Addis Ababa that can change the image of the city and improve the lives of thousands of Ethiopians by creating job opportunities and solving housing problems. The UAE also funded infrastructural projects, like the development of port Barbara in Somalia, which DP world company has signed an agreement to give a 19 percent share of the port of Berbera to Ethiopia and the highway road that connects the Barbara port of Somaliland to Ethiopia. The UAE's Khalifa Fund for Enterprise Development (KFED) has also signed a 100 million US dollars (Ethiopian News Agency, 2020) agreement to support small-scale and medium enterprises and youth and women projects in Ethiopia. In 2014, about 66 UAE investors with a combined capital of 335.7 million USD have invested in Ethiopia. In 2019, the number of investors has significantly increased and their capital reached over 2.3 billion USD (Derso, 2020). Saudi Arabia also offered Ethiopia a loan of 140 million USD to support the new government's economic plans and the development of infrastructure in 2019.

Its rivalry with the neighboring countries (mainly Saudi Arabia and the UAE) and the subsequent blockade imposed by Saudi led coalition encouraged Qatar to enhance its presence in Ethiopia. According to the International Crisis Group (2019), Qatar was importing 80 percent of its food and related commodities from its neighbors. When its neighbors imposed the blockade in 2017, Qatar began to look at other possible options to secure its short-term and long-term food demand. Ethiopia was one of the best options for its investment in the agriculture sector. Qatari companies are also working to invest in the area of real estate development.

As part of its effort to enhance the relations between the two states, Qatar Fund for Development (QFFD) has made a grant agreement with Ethiopia in 2020, to build and furnish a high-standard hospital (Reliefweb, 2020).

In general, the trade relations between the two sides and the flow of the Gulf investment have been growing for the last two decades. Particularly, in the last three years, the GCC countries' economic engagements with Ethiopia have shown significant improvements. However, as compared to the huge economic potentials of Ethiopia and the massive capital and demand for agricultural products of the GCC countries, there is still a huge imbalance.

\subsection{Political Relations}

Ethiopia and the GCC States need each other to achieve their political interests in the Horn of Africa. However, their political relationship was not as progressive as their economic relations. It was/is inconsistent, unsustainable, and vola- 
tile that influenced by the long-standing mutual mistrust, suspicion, and rivalry. Some GCC countries' support of the radical Islamist groups in Somalia, their close political relations with Eritrea, and their support to Egypt's claim on the Nile disputes have further undermined Ethio-GCC's political relations in the last two decades. This was witnessed by the bilateral relations of Ethiopia with each GCC country and its overall relations with all GCC countries.

Ethiopia's political and diplomatic relation with Qatar from 2008 to 2013 was a reflection of the complicated and mysterious relations between Ethiopia and the Gulf. Their diplomatic relationship deteriorated following Ethiopia's decision to break its relation with Qatar. In April 2008, Ethiopia severed diplomatic relations with Qatar, accusing Qatar of creating instability in the Horn of Africa by supporting extremist elements and armed opposition groups. Ethiopia was unhappy with Qatar's strong ties with Eritrea and its engagement in Somalia supporting the Islamist militants. The government of Ethiopia also suspected that Qatar was undermining Ethiopian security using its media, Al Jazeera (Birara, 2013). Mentioning Qatar's anti-Ethiopia approach as a premise, the Ethiopian government broke its diplomatic relations for a while. Nonetheless, after an open discussion between the leaders of the two countries, they agreed to officially resume full diplomatic relations in November 2012. In April 2013, the Emir of Qatar visited Addis Ababa and the two countries have signed several agreements to enhance cooperation (Mesfin, 2016). Gradually, Qatar loosens its tie with Eritrea, as it enhanced its diplomatic and economic ties with Ethiopia. In 2017, there have been frequent high-level visits between both sides and they signed additional agreements and a memorandum of understandings to improve bilateral relations.

Another indication of the strained political relationship between Ethiopia and the Gulf was some GCC countries' close friendship with Ethiopia's adversary, Eritrea. As mentioned above, Qatar's strong tie with Eritrea was one of the reasons behind Ethiopia's decision to break diplomatic relations with Doha. Similarly, Saudi Arabia's and the UAE's close relations with Eritrea have also affected their relations with Ethiopia. Following the outbreak of the Yemen crisis, Saudi Arabia and its allies sought to use port Assab of Eritrea as a military base for their military campaign in Yemen. As reported by the International Crisis Group (2018), Saudi signed a security agreement with Eritrea in April 2015 to use Assab. Under this agreement, the UAE built a naval and airbase at the port of Assab. This Riyadh's and Abu Dhabi's actions were seen by Ethiopia as a critical national security threat and a violation of the UN Security Council sanction imposed on Eritrea for its alleged role in destabilizing the region by supporting terrorist groups in Somalia. The Ethiopian government was openly criticized Saudi-UAE's move that it would threaten Ethiopia's security and destabilize the peace and security of the region. Their presence in Eritrea further deteriorated the Ethio-Gulf relations.

However, in November 2016, a high-level official visit to Saudi Arabia was 
made by the former Ethiopian Prime Minister Hailemariam Desalegn, which intended to ease the tension between the two countries caused by Saudi Arabia's security agreement with Eritrea and improve their economic cooperation. He met Saudi Crown Prince Mohammed bin Naif bin Abdulaziz and discussed bilateral and regional security issues. Weeks after Hailemariam visited Saudi Arabia, a high-level Saudi delegation led by the senior advisor at the Royal court of the royal kingdom of Saudi Arabia, Ahmed Alkhateeb, visited Ethiopia and the two countries agreed to enhance their cooperation in investment and trade and to work together on peace and security issues in the Horn of Africa and the Middle East (Tekle, 2016).

As shall be discussed below, the GCC countries' full support of Egypt's Nile water claim was another indication of the strained political relations between Ethiopia and the Gulf. Each country individually and collectively expressed its strong support to Egypt, which is against the national interest of Ethiopia.

Although its sustainability is still doubtful, the Ethio-Gulf political relations have shown meaningful change following the 2018 political transition in Ethiopia. The political and economic crises in Ethiopia forced the new government to seek foreign aid to overcome the critical shortage of foreign currency. It was a time when the new government was looking for a viable foreign partner that could provide economic support and alleviate its foreign exchange deficit. At the same time, the regional competition between Saudi Arabia, the UAE, Bahrain, and their allies on one side and Qatar, Turkey, and others on the other side has changed the regional politics and GCC countries' foreign policies towards the Horn of Africa. These competing powers, especially the GCC countries, have been trying to deepen their influences in the region to challenge one another. As a result, Saudi Arabia, the UAE, and Qatar were seeking to shape and influence political transitions in Ethiopia.

These domestic and regional political dynamics had a direct implication on Ethiopia's relations with these countries. These dynamics compelled Ethiopia to turn to Saudi Arabia and the UAE in part because it needed funding; at the same time tried to balance between the two rival groups by maintaining its good relations with Qatar. Recently, the relations between Ethiopia and the GCC countries are maintaining relatively a healthy and continuous development tendency with mutual high-level visits. Several high-level visits have been made between Ethiopia and the GCC countries since 2018 to enhance cooperation, trade, and investment.

In May 2018, Abiy Ahmed traveled to Saudi Arabia and met with the Saudi crown prince, Mohammed bin Salman bin Abdulaziz Al-Saud. The two leaders have discussed bilateral and regional issues (KFCFIS, 2020). In May 2018, Ethiopia's prime minister visited the UAE and discussed the crown prince of Abu Dhabi on ways of enhancing bilateral ties between the two countries and other regional issues. A month after Abiy's visit, the crown prince of Abu Dhabi visited Ethiopia and made talks with his counterpart Abiy Ahmed on various is- 
sues and agreed to consolidate the cooperation and friendship, and strategic partnership between them (Wam, 2018). The two leaders also met and discussed bilateral issues in March 2019 when Abiy traveled to Abu Dhabi for the second time within a year. Prime Minister Abiy Ahmed also visited Qatar to discuss regional and bilateral issues in March 2019 (Preeth, 2020). These official visits and agreements have enhanced the cooperation and mutual partnership between Ethiopia and the Gulf.

\section{Opportunities to Enhance Ethiopia's Relations with the GCC Countries}

Given the centuries-old historical and religious ties between Ethiopia and the GCC countries, there are many opportunities for greater economic and political relations based on mutual benefits. Some of these potential opportunities for further integration and cooperation between them are discussed in this section.

\subsection{Economic Opportunities}

Ethiopia is one of the fastest economies of sub-Saharan Africa, which registered an average of 9.4 percent growth a year from 2010/11 to 2019/20 (The World Bank Ethiopia, 2021). Its economy is vastly dependent upon agriculture, which accounts for 85 percent of the total employment. Ethiopia's export commodities are dominantly agricultural products like coffee, oilseeds, live animals, and others. On the other side, the GCC countries are entirely dependent on imported agricultural products, which would make them continue to be the main destinations of Ethiopian export commodities.

Demographically, Ethiopia is the second-most populous African country with more than 110 million populations. The productive young age group is around 60 percent of the population (Ethiopian Investment Commission, 2021). This makes Ethiopia the potential market for the GCC countries' products and provides affordable labor for Gulf investors in Ethiopia.

Alongside human resources, Ethiopia has enormous irrigable farmlands with fertile soils, suitable climate for the production of a wide range of crops, fruits, and vegetables that can attract foreign direct investment. GCC countries, on the other hand, have the desire and capacity to take advantage of these favorable economic and investment opportunities in Ethiopia. Since most of these countries are dependent on imported foods, they need to invest, mainly in the agriculture sector, which would benefit both sides by strengthening mutual cooperation and developments.

Ethiopia's geographical proximity (Figure 1) to the GCC countries, its geostrategic location that serves as a gateway to the African continent, its Africa's leading efficient and strong airline, growing road and railway infrastructure networks connecting it with its surrounding African countries, and the ongoing power generating projects are also other potential opportunities that make it an attractive destination for Gulf investment and trade. 


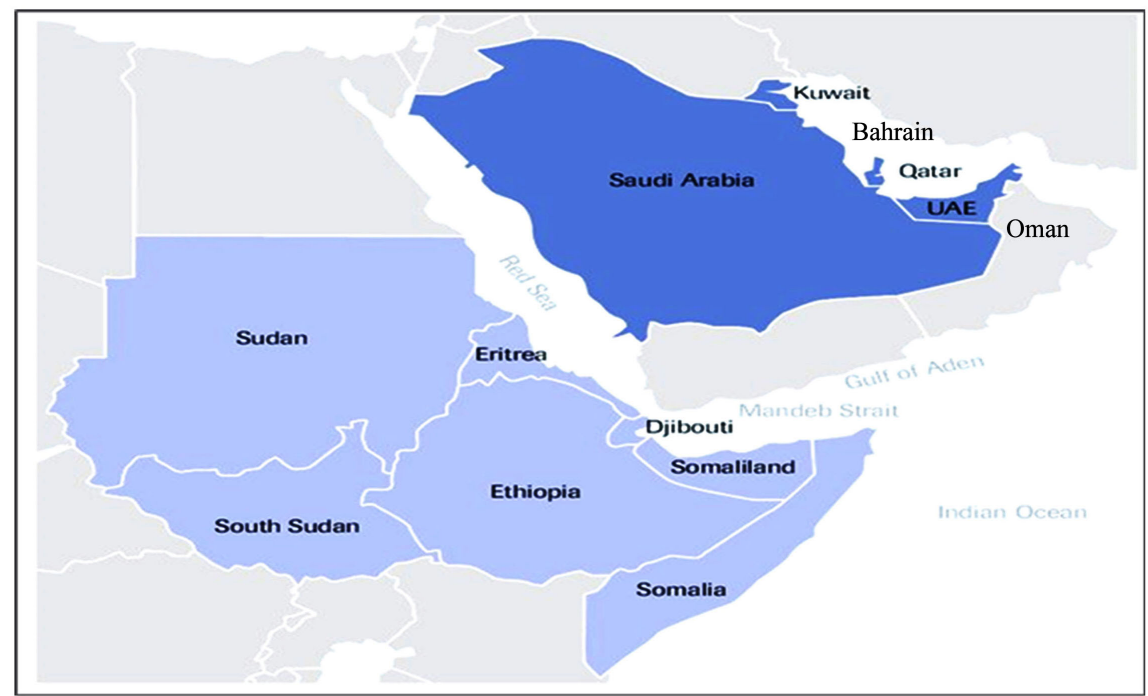

Figure 1. Map of the Horn of Africa and the Gulf (Source: Meester, J. Berg, W. \& Verhoeven, H., 2018).

\subsection{Cultural Heritages as a Tourist Attraction}

The people of Arab and Muslim countries have developed the culture of traveling across the world as tourists, especially during the hot season. Every year, millions of tourists from these countries visit different parts of the world. As reported by Arab News on August 14, 2016, the GCC countries spent around 71 billion USD a year on tourism abroad. The Saudis spent $\$ 25.1$ billion, while the Emiratis, Qataris, and Kuwaitis spent $\$ 17.7$ billion, $\$ 12.9$ billion, and $\$ 12.3$ billion respectively.

Ethiopia is the home of many historical, traditional, and religious heritages and natural attractions that can easily attract the people of the Arab and Muslim world. Ethiopia has a unique place in Islamic history. It is the land of the first "hijra", where the first groups of Muslim migrants were sheltered. Ethiopia is also the origin of Bilal, the first Muazzin (caller for Islamic Prayer) who had close intimacy with the prophet himself. Ummu Aymen, the nurse of Prophet Mohammed was also from Ethiopia.

Another most important religious and historical heritage in Ethiopia is the mosque of Al-Nejash. Al-Najash is a place where the first group of followers and families of Prophet Mohammed has been settled. The Mosque of Nagash is the first Mosque built by the migrants in 615 at Al-Najash. In addition, since the Middle Ages, Islamic states and civilizations have been flourished in different parts of today's Ethiopia. One of the centers of Islamic culture and heritage was the walled city of Harar, which is the $4^{\text {th }}$ Islamic holy city next to Mecca, Medina, and Jerusalem (Preeth, 2020). Since the ninth century, Harar was serving as an Islamic and Arabic education center of the Horn of Africa and was registered by UNESCO in 2006 (Ahmed \& Akbaba, 2018).

Even though it was not well promoted, Ethiopia is still a special place for Muslims of the world. These religious heritages could be potential tourist attractions 
from Muslim countries if properly promoted. Therefore, the availability of these religious heritages is an opportunity to attract more tourists from the Gulf and consolidate Ethiopia's ties and cooperation with these countries. It will also promote people-to-people relations, enable regional integration and provide economic benefits to Ethiopia.

\subsection{Ethio-Eritrea Rapprochement}

The Ethio-Eritrea rapprochement since 2018 has ended the two decades of "no war no peace" situation between the two countries. The leaders of the two countries have signed a "joint declaration of peace and friendship" on July 9 and a peace agreement in September 2018. The benefits of the peace deal are beyond the two countries; it is an important source of regional political, economic, and social stability. It is helping to promote diplomatic relations, trade, and economic development, people-to-people relations in the Horn of Africa.

Ethiopia's rapprochement with Eritrea would also help Ethiopia to access Eritrea's ports, which would benefit both countries. It would also enable the GCC countries to access the second African most populous country and the rapidly growing economy, Ethiopia. Following the peace agreement, the UAE Company, Dubai Ports World, has shown its interest to help the development of port Assab. In 2018, the UAE also announced a project to construct a pipeline connecting port Assab to Addis Ababa, Ethiopia (Lons, 2018). These infrastructure developments will enhance GCC countries' access to Ethiopia's agricultural products also.

Apart from its direct benefits, the peace agreement between Ethiopia and Eritrea can avoid hostility and mutual suspicion between Ethiopia and the GCC countries. Before the peace agreement, the GCC countries' strong ties with Eritrea had been perceived as security threats by Ethiopia. For example, as mentioned above, the establishment of a military base by the UAE in Eritrea's port of Assab following the Yemen war was a security threat to Ethiopia. Similarly, Qatar's closest ties with Eritrea before 2008 posed a security threat to Ethiopia, led to strained diplomatic relations with Qatar. Thus, the current Ethio-Eritrea peace agreement is an opportunity to further strengthen Ethiopia's ties with the GCC countries as it has removed many barriers that existed in the smooth relationship of Ethiopia with the GCC Countries.

\section{Challenges of Ethiopia's Relations with the GCC Countries}

As argued by the theory of interdependence, in a mutually dependent relationship, both benefits and costs are expected. In this regard, despite the growing economic cooperation and mutual benefits, the Ethio-Gulf relations were also characterized by competition and conflicts. Some challenges hinder the effectiveness and sustainability of the economic and political partnership, which is based on mutual benefit and development. Many of the challenges are the result of a long-standing relationship of mutual suspicion and mistrust. 


\subsection{Elites Perception as a Source of Distrust}

In Ethiopia and the GCC countries, religion and politics are intertwined as their people are deeply religious. Until 1974, Orthodox Christianity was declared as an official state religion in Ethiopia. Although religion and state have been separated since 1974, Ethiopian politics was unable to detach itself from the influence of religious narratives for years. Likewise, it is impossible to see politics independent of religion (Islam) in the GCC countries. Thus, religion had an impact in shaping the perception of the political elites of both sides, which in turn influenced the foreign relations between Ethiopia and GCC countries.

Although Ethiopia is a multi-religious country, it was regarded by the Arab World as a Christian country. As a result, some Muslim GCC countries developed anti-Ethiopian sentiments and supported separatist movements that undermined the unity and territorial integrity of Ethiopia. As argued by Seifuddin Adem Hussien (2019), since the beginning of the Eritrean struggle, the Arabs perceived it as a Muslims' struggle to liberate themselves from Christian domination. Thus, they provided continuous support to the Eritrean separatist group.

Similarly, due to the Arabs engagement in the Eritrean case and their support to Somalia during the Ethio-Somalia war, Ethiopian elites have become suspicious of the Arab world. They developed a strong belief that the Arab countries are against Ethiopia's national unity and territorial integrity. Still, there are tendencies among some political elites and intellectuals to generalize all Arab countries as historical enemies of Ethiopia. Due to this scenario, they rather prefer to be away from Gulf or other Arab states as possible. However, this has never been a state's stance.

Thus, some Ethiopian and the Gulf-countries elites' perceptions have a negative influence on Ethiopia's relations with the GCC countries.

\subsection{The Influence of the Nile Issue}

Another barrier and significant source of tension that affects Ethiopia's relations with the Arab world is the Grand Ethiopian Renaissance Dam (GERD). Ethiopia, the source of more than 85 percent of the flow of the Nile River, has completed almost 80 percent of the construction of the dam on the river, which started in 2011. The completion of the dam is expected to solve the country's severe power shortage and will enable more than 60 percent of the Ethiopian population who live in darkness to access electricity. The dam will also support Ethiopia's efforts to pull its people out of absolute poverty. Nevertheless, the construction of the dam has worried the downstream countries, mainly Egypt, a longstanding partner of Saudi Arabia and the UAE. The Nile issue is another challenge that strained the relation on both sides.

For centuries, Egyptian leaders have designed and implemented different strategies to maintain their water interest by keeping Ethiopia weak. One of the long-standing strategies is securing the support of the Arab countries on the issue of the Nile controversy. Egypt has succeeded in convincing the Arab world 
that Ethiopia is posing threat to Egypt's water rights. Due to its strategic importance to the Arab world, the GCC countries see the stability of Egypt as critical to maintaining the regional balance of power. To this end, they support Egypt's claim on the filling of the dam and related issues, which is against Ethiopia's interest.

Although Ethiopia has repeatedly stated that it is constructing the dam in a manner that does not harm the lower riparian countries, Egypt is firmly opposing the dam. It is clear that the dam will reduce the risk of floods and regulate the flow of the water throughout the year, which enable Sudan to expand irrigated agriculture. As described by Alex de Waal (2019) and Nima Khorrami (2020), the GERD will also benefit Saudi Arabia and the UAE who have leased farmlands in Sudan and engaged in agriculture to ensure their food security. However, whenever the issue of GERD rose by Egypt as an agenda in any Arab League's meeting, the GCC countries support Egypt. Even though Saudi Arabia and the UAE have established good relations with Ethiopia since 2018, they frequently sided with Egypt and echo its claim for historic water rights in recent Arab League meetings. As reported by Saudi Gazette, on March 31, 2021, Saudi Arabia, along with its allies Kuwait, Oman, and Bahrain has issued a statement expressing its solidarity with the downstream countries in their dispute over GERD. Saudi's foreign ministry said, "Saudi Arabia sees Egypt and Sudan's water security as an integral part of the broad Arab water security."

Ethiopia has strictly criticized the Arab League's resolutions on GERD several times. For instance, it entirely rejects the resolution issued by the League on 05 March 2020 stating "it gives blind support to a member state without taking into consideration key facts at the center of the GERD talks" (The Ministry of Foreign Affairs of Ethiopia, 2020). This shows that the GCC countries' stance on Ethiopia's dispute with Egypt on the Nile politics is affecting the Ethio-Gulf political relations.

\subsection{Mistreatments of Ethiopian Migrants in the GCC Countries}

Ethiopia is one of the largest exporters of labor to the GCC countries. In recent decades, thousands of Ethiopians, especially unskilled young women, are migrating to the GCC countries in search of a job as domestic workers. This labor migration has been one feature of the relationship between Ethiopia and the GCC countries. According to the Ministry of Foreign Affairs of Ethiopia, more than one million Ethiopian migrant workers are living in the GCC countries. The presence of many Ethiopian migrants in the Gulf, especially in Saudi Arabia, the UAE, Qatar, and Kuwait is believed to have a positive impact on Ethiopia's relations with these countries. They are expected to play an important role in creating economic ties and strengthening people-to-people relations between the two sides.

Nevertheless, the mistreatment and violation of the human rights of Ethiopian migrant workers in some GCC countries have become a huge concern for Ethio- 
pians and the Ethiopian government. As reported by many media outlets and international organizations, Ethiopians living in the GCC countries, mainly in Saudi Arabia, have been suffering from racial discrimination, physical and sexual abuses, arbitrary arrests, poor working conditions, low and tardy pay, and other kinds of violence.

From November 2013 to March 2014, Saudi Arabia deported more than 163,000 Ethiopian migrants as part of its campaign to expel migrants without the required resident or work permits (Walk Free Foundation, 2019). Again, from May 2017 to March 2019, the Saudi government has arrested and deported around 260,000 Ethiopians (Human Rights Watch, 2019). In 2020, the Saudi government has expelled additional thousands of undocumented Ethiopians due to the fear of the spread of COVID 19. During the process of deportation, it was reported that the properties of many Ethiopians have been confiscated (Walk Free Foundation, 2019). Saudi Arabia's measures have been condemned by the United Nations, Human Rights Watch, European Parliament, and others. The United Nations had raised its concern and urged to suspend deportation when Saudi Arabia started to deport Ethiopians during the pandemic in 2020. However, Riyadh had continued to deport. European Parliament has also issued a resolution on August 08, 2020, condemning the mistreatment of Ethiopian migrants by the Saudi authorities and calling for an immediate release of Ethiopian detainees. As indicated in the resolution, about 30,000 Ethiopians, including children and pregnant women, were "arbitrarily detained under horrific conditions," which violates human rights.

Saudi Arabia has stepped up its efforts to deport tens of thousands of Ethiopians indiscriminately in the wake of the second round water filling of the Grand Ethiopian Renaissance Dam, which appears to be putting pressure on Ethiopia in the GERD negotiation. This shows Riyadh's intention to use the issue of Ethiopian migrants in Saudi Arabia as a tool to impose its political interests on Ethiopia.

These kinds of ill-treatments and frequent violations of human rights against Ethiopian migrants are very common in many other GCC countries, including the UAE, Qatar, and Kuwait.

The Ethiopian government has attempted to contain illegal migration of its citizen to the Middle East, especially, following the mass deportation of illegal Ethiopian labor migrants from Saudi Arabia in 2013. It also suspended the legal migration to the Arab countries in search of a job. Ethiopia's measure has increased the illegal migration of Ethiopians to the GCC countries (Schröder, 2015). According to IOM, at least 400,000 Ethiopians have illegally migrated to the GCC countries since 2017 (IOM, 2020). Although the illegal migration of Ethiopians has caused various problems to the GCC countries, the treatment of these Ethiopians should be in a manner that does not violate their human rights and harm the relations between the peoples and governments of Ethiopia and the Arab countries. The return of those without legal residency or work permits 
should be done in consultation with the Ethiopian government. However, as reports indicated, Saudi Arabia deported Ethiopians without proper consultation with the Ethiopian government, which causes a huge burden of rehabilitation on Ethiopia's side. These practices can undermine the efforts to improve the already fragile and skeptical relations between Ethiopia and the GCC countries. It also creates a negative perception among Ethiopian people towards Arab countries.

\section{Conclusion}

This paper examined Ethiopia's economic and political relations with the GCC countries, the potential opportunities, and the challenges since 2000. Although it assessed all GCC countries, the paper emphasizes Ethiopia's relations with the three politically and economically dominant countries of the region, Saudi Arabia, the UAE, and Qatar.

The paper finds out that despite their historical, cultural, religious, and economic attachments, the relations between Ethiopia and the GCC countries have been characterized by culturally embedded mistrusts, suspicions, competitions, rivalries, and hidden agendas for influence for many years. Although Ethiopia's relations with the GCC countries have shown progress during the rule of EPRDF, it was not as to the level of expectation. The economic relations between Ethiopia and the GCC countries, particularly Saudi Arabia, the UAE, and Kuwait have been evolving since 2000. The study identifies that for the last three years, Ethiopia's overall relations with the GCC countries improved significantly. The domestic political and economic reforms and the new foreign relation approach of the Ethiopian government towards the Gulf combined with the growing interest of the GCC countries in Ethiopia has been strengthening their relationships. However, the political relations between the two sides were not as smooth and consistent as their economic relations. It lacks continuity and was influenced by long-standing mutual suspicion and mistrust. It is also not evenly balanced mutual dependence; rather the interdependence relationship is asymmetric as the Gulf countries are economically more powerful than Ethiopia.

The opportunities to further boost these growing relations are Ethiopia's potential market for the Gulf products, its untapped resources, such as fertile land suitable for irrigated farming, affordable labor, and its geographical proximity, and others. These economic opportunities attract the GCC countries' investment, mainly in the agricultural sector to sustain their food security. Availability of numerous cultural (Islamic) heritages and natural attractions is another opportunity to attract tourists from the GCC countries that would maximize the economic and people-to-people ties. The Ethio-Eritrea rapprochement is also another opportunity to strengthen the smooth and mutually beneficial relationship between Ethiopia and the GCC countries.

Aside from the opportunities, the challenges that strained these relations were also the other focus of the study. On that matter elites' mutual suspicion, the GCC countries siding with Egypt on the Nile disputes and the mistreatment of Ethiopian workers in some GCC countries are among the challenges that un- 
dermine the relations between Ethiopia and the GCC countries.

\section{Limitation of the Study}

One of the limitations to the study is its lack of updated data about Ethiopia's relations with some of the Gulf countries, like Oman and Bahrein. However, this limitation was not considered significant enough to compromise the overall research findings and argument.

\section{Conflicts of Interest}

The author declares no conflicts of interest regarding the publication of this paper.

\section{References}

Adula, N. G. (2019). Ethiopian Foreign Policy under Military and EPRDF Regimes: Changes and Continuities. Journal of Political Science and International Relations, 2, 25-31.

African Union (2020). African Trade Statistics. 2020 Year Book. African Union. https://au.int/sites/default/files/documents/39607-doc-af-trade yearbook2020 v4 com p-compresse 1.pdf

Ahmed, M. J., \& Akbaba, A. (2018). The Potential of Halal Tourism in Ethiopia: Opportunities, Challenges and Prospects. International Journal of Contemporary Tourism Research, 2, 13-22. https://doi.org/10.30625/ijctr.397499

Arab News (2016, August 14). KSA Tourists Cough up \$25.1 Billion Abroad. Arab News. https://www.arabnews.com/node/969511

Birara, A. (2013). Zigzag Diplomacy: Ethiopian-Qatari Diplomatic Relations and Their Implications. Aljazeera English. https://studies.aljazeera.net/ar/node/1300

Cafiero, G., \& Cok, C. (2020, June 25). Divide and Survive: Ethiopia's Relations with the Gulf and Turkey. The New Arab.

https://english.alaraby.co.uk/english/indepth/2020/6/25/divide-and-survive-ethiopia-b alances-gulf-turkey-ties

De Waal, A. (2019). Pax Africana or Middle East Security Alliance in the Horn of Africa and the Red Sea? World Peace Foundation Conflict Research Programme, Occasional Paper No. 17.

Derso, B. (2020, April 7). Economic Diplomacy Witnesses Huge Gulf Investment. The Ethiopian Herald, 76, p.

https://www.press.et/english/wp-content/uploads/2020/04/The-Ethiiopian-Herald-Apr il-7 opt.pdf

Encyclopedia of the Nations Ethiopia (2021). Foreign Trade. https://www.nationsencyclopedia.com/Africa/Ethiopia-FOREIGN-TRADE.html

Erlich, H. (1994). Ethiopia and the Middle East. Lynne Rienner Publishers, Inc.

Erlich, H. (2006). Saudi Arabia and Ethiopia: Islam, Christianity, and Politics Entwined. Lynne Rienner Publishers.

Ethiopian Investment Commission (2021, April 24). Why Invest in Ethiopia? http://www.investethiopia.gov.et/why-ethiopia/why-invest-in-ethiopia

Ethiopian News Agency (2020, August 15). UAE Companies Eager to Invest in Ethiopia: Ambassador Alrashedi. https://www.ena.et/en/? $\mathrm{p}=16328$ 
Girma, Z. (2020, February 1). Ethio-Qatar Strategic Cooperation in Trade and Investment. The Ethiopian Herald. https://www.press.et/english/?p=18412\#

Human Rights Watch (2019). Ethiopians Abused on Gulf Migration Route: Trafficking, Exploitation, Torture, Abusive Prison Conditions.

https://www.hrw.org/news/2019/08/15/ethiopians-abused-gulf-migration-route

Hussien, A. S. (2019). Islam, Christianity and Ethiopia's Foreign Policy. Religious Studies: an International Journal, 7, 17-36.

International Crisis Group (2018). The United Arab Emirates in the Horn of Africa. Crisis Group Middle East Briefing No. 65, International Crisis Group.

International Crisis Group (2019). Intra-Gulf Competition in Africa's Horn: Lessening the Impact. Middle East Report No. 206, International Crisis Group.

IOM (International Organization for Migration) (2020, May 22). New Study on Ethiopian Migrants to the Gulf Finds Many Unaware of Dangers.

https://www.iom.int/news/new-study-ethiopian-migrants-gulf-finds-many-unaware-d angers

KFCFIS (King Faisal Center for Research and Islamic Studies) (2020). Red Sea Peace Initiatives: Saudi Arabia's Role in the Eritrea Ethiopia Rapprochement. King Faisal Center for Research and Islamic Studies.

https://www.kfcris.com/pdf/d20bbcf408a7f0d61ee0858c8a6db5fd5ee0744ccd381.pdf

Khorrami, N. (2020). Deadlock on the Nile. Carnegie Endowment for International Peace. https://carnegieendowment.org/sada/82344

Lons, C. (2018). Saudi Arabia and the UAE Look to Africa. Carnegie Endowment for International Peace. https://carnegieendowment.org/sada/77561

Meester, J., Berg, W., \& Verhoeven, H. (2018). Riyal Politik: The Political Economy of Gulf Investments in the Horn of Africa. CRU Report. Netherlands Institute of International Relations 'Clingendael.

Mesfin, B. (2016). Qatar's Diplomatic Incursions into the Horn of Africa. Institute for Security Studies, East Africa Report, Issue 8. Qatar's Diplomatic Incursions into the Horn of Africa.

https://issafrica.org/research/east-africa-report/qatars-diplomatic-incursionsinto-the-h orn-of-africa

Ofcansky, P. T., \& Berry, L. V. (Eds.) (1991). Ethiopia: A Country Study. GPO for the Library of Congress. http://countrystudies.us/ethiopia/

Preeth, R. (2020). Qatar-Ethiopia Ties Growing to Unprecedented Level, Says Envoy. Qatar Tribune.

https://www.qatar-tribune.com/news-details/id/182478/qatar-ethiopia-ties-growing-tounprecedented-level-says-envoy

Rana, W. (2015). Theory of Complex Interdependence: A Comparative Analysis of Realist and Neoliberal Thoughts. International Journal of Business and Social Science, 6, 290-297.

Reliefweb. (2020, March 29). Qatar Fund for Development Finances the Construction of a Specialized Kidney-Care Hospital in Addis Ababa.

https://reliefweb.int/report/ethiopia/qatar-fund-development-finances-construction-sp ecialized-kidney-care-hospital-addis

Robert, K., \& Nye, J. (1977). Power and Interdependence: World Politics in Transition. Little, Brown \& Co.

Saudi Gazette. (2021, March 31). Saudi Arabia Rallies Gulf Support for Egypt and Sudan over Nile Dam Row. 
https://saudigazette.com.sa/article/605047/SAUDI-ARABIA/Saudi-Arabia-rallies-Gulfsupport-for-Egypt-and-Sudan-over-Nile-dam-row

Schröder, G. (2015). Migratory and Refugee Movements in and from the Horn of Africa. Friedrich-Ebert-Stiftung/Africa Department Hiroshimastr.

https://library.fes.de/pdf-files/iez/12081.pdf

Sorenson, J. (1992). History and Identity in the Horn of Africa. Dialectical Anthropology, 17, 227-252. https://doi.org/10.1007/BF00243364

T.G. (2019). Why Are Gulf Countries So Interested in the Horn of Africa? The Economist. https://www.economist.com/the-economist-explains/2019/01/16/why-are-gulf-countri es-so-interested-in-the-horn-of-africa

Tekle, A. (1989). The Determinants of the Foreign Policy of Revolutionary Ethiopia. The Journal of Modern African Studies, 27, 479-502. https://doi.org/10.1017/S0022278X00020395

Tekle, T. (2016). Saudi High-Level Delegation Concludes Ethiopia's Visit. Sudan Tribune. https://sudantribune.com/spip.php?article61151

The Ministry of Foreign Affairs of Ethiopia (2020, March 6). Statement on the Arab League's 'Resolution' Concerning the GERD. Facebook. https://www.facebook.com/MFAEthiopia/posts/3433008856726333

The World Bank in Ethiopia (2021, March 18). Overview, The World Bank. https://www.worldbank.org/en/country/ethiopia/overview\#: :text=Ethiopia\%20aims\% 20to\%20reach\%20lower,to\%20COVID\%2D19\%20(cornaviruspandemic

Trading Economics (Last Checked, 3 April 2021). India Inflation Rate Falls to 5-Month Low. https://tradingeconomics.com/

UNCTAD (United Nations Conference on Trade and Development) (2021). International Investment Agreements Navigator: Ethiopia.

https://investmentpolicy.unctad.org/international-investment-agreements/countries/67 lethiopia

Walk Free Foundation (2019). Ethiopia's New Migration Policy: A Positive Step but Continued Scrutiny Needed. (Last Checked 2 March 2021)

Wam (2018, June 16). Mohamed Bin Zayed, Ethiopian PM Hold Talks. Emirates 24/7. https://www.emirates247.com/news/government/mohamed-bin-zayed-ethiopian-pm-h old-talks-2018-06-16-1.670320 